Copyright (C) 2021 by Cherkas Global University

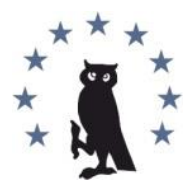

Published in theUSA

Propaganda in the World and Local Conflicts

Has been issued since 2014 .

E-ISSN 2500-3712

2021. 8(2): 59-69

DOI: 10.13187/pwlc.2021.2.59

https://pwlc.cherkasgu.press

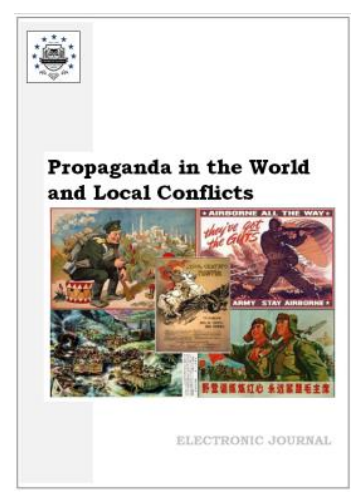

\title{
Articles
}

\section{Elements of Propaganda in "Essays on the Geography of the Almighty Don Host" by V.V. Bogachev (1919)}

\author{
Artem Yu. Peretyatko a, b, * \\ a Cherkas Global University, Washington, USA \\ b Volgograd State University, Volgograd, Russian Federation
}

\begin{abstract}
The paper highlights "Essays on the geography of the Almighty Don Host" (Ocherki geografii Vsevelikogo Voyska Donskogo), a textbook on the geography of the Don region, which came to print amid the Civil War thanks to the initiative of a Don Ataman, P.N. Krasnov. The paper shows that the textbook, in combination with the "Don chrestomathy" (Donskaya khrestomatiya), created in the same period, was supposed, as the authors devised it, to imbue students at Don schools with devotion to their homeland, to shape them as "useful servants of the Almighty Don Host". The book, among other things, contained the propaganda of the military devotion of Don Cossacks.

Analyzing the text of "Essays on the geography of the Almighty Don Host" and looking at it through the lens of the Don social ideas, which existed at the turn of the 2oth century, the author concludes that the majority of the ideological constructs, which V.V. Bogachev promulgated, were not novel. V.V. Bogachev, like several earlier authors, championed the importance of the Cossacks' military devotion and argued that future generations of Cossacks should be prepared to defend their land. However, as he formulated the positive values that Cossacks stood guard of, V.V. Bogachev attached particularly great virtue to irrational love for the Motherland, regardless of whether it was justified or not. Moreover, V.V. Bogachev insisted that Cossacks were superior in their moral qualities to Great Russians whom his text styled in the obvious image of "strangers". Although similar views could be found among hard-right Don authors before 1917, V.V. Bogachev was the first to include them into a textbook and substantiate them with a unique Cossack heritage, on top of that. The author comes to the conclusion that V.V. Bogachev's book clearly demonstrates how, in times of war, the declared propaganda of "love for the Cossackdom" transforms into the propaganda of xenophobia with only a thin line separating it from radical nationalism.
\end{abstract}

Keywords: Don Cossacks, Almighty Don Host, Civil War, military propaganda, school textbooks, V.V. Bogachev.

\section{Introduction}

In 1919, at the height of the Civil War, Novocherkassk saw publication of two books intended for Don schools. One of the books - "Essays on the geography of the Almighty Don Host" by V.V. Bogachev - was created, as the author himself wrote in the foreword, "on the proposal of $\mathrm{g}<$ ospodin $>$ Don

\footnotetext{
${ }^{*}$ Corresponding author

E-mail addresses: ArtPeretatko@yandex.ru (A.Yu. Peretyatko)
} 
Ataman" (further it becomes clear that he meant P.N. Krasnov, not A.P. Bogaevskii, who succeeded him in February 2019) (Bogachev, 1919). The second book, "Don chrestomathy", was in fact "an edition of the Don Host", its flyleaf read (Donskaya khrestomatiya, 1918: forzats). Of particular interest is the editorial board of the chrestomathy: it included people of rather divergent stances, such as a far right Don regional historian, Kh.I. Popov, and a former liberal State Duma deputy from the Don Host, A.I. Petrovskii (Donskaya khrestomatiya, 1918: forzats). We will see below that the publication of the two books was a single project that was given a major priority by the Krasnov administration. The new state, the Almighty Don Host, needed textbooks to promote its ideological pillars.

Already after P.N. Krasnov's resignation, the Don Host published another book, "Essay on the political history of the Almighty Don Host", and this time it specified no author, but had a portrait of Ataman A.P. Bogaevskii on the flyleaf (Ocherk politicheskoi istorii..., 1919). The foreword informed that the book was published in three versions: in Russian, French and English, to "make our Allies aware of the historical fate and political role of the Don Cossackdom" (Ocherk politicheskoi istorii..., 1919: I). Even the Russian edition was in the first place designed not for Russians, but for the "newly established Slavic states akin to us" (Ocherk politicheskoi istorii...,, 1919: I). Therefore, despite the awfully harsh conditions of the Civil War, the Almighty Don Host rolled out a sufficiently large-scale publishing efforts by printing books to propagandize its ideas. And the conditions indeed made book printing a very challenging undertaking: for example, V.V. Bogachev openly complained that he did not have many of the resources needed at hand, and the printing of his "Essays" was slowed down as typesetters were mobilized and there was a lack of good paper (Bogachev, 1919: b. s.). Publishing as many as three books in such conditions in a short time definitely indicates the crucial role attached by the Don administration to propaganda and indoctrination of the younger generation and allies in its ideology.

A reservation should be made right away that, of course, we cannot speak about a coherent and explicitly formulated ideology in the Almighty Don Host. The policies, pursued by the administrations of P.N. Krasnov and A.P. Bogaevskii, were in stark contrast, as well as Kh.I. Popov and A.I. Petrovskii were far from sharing the same views. However, against all odds, they managed to frame a rather adequate compromise concept, substantiated in the forewords to the books, at least in "Essays on the geography of the Almighty Don Host" and "Don chrestomathy", intended for schools. They emphasized that love for the homeland and its history was a quality of any normal human being, fostered in childhood, but there were no dedicated textbooks for Don schools on local history, geography and literature. "Modern pedagogy prescribes to begin the study of geography not with a general course, not with learning terminology, not with definitions of what a peninsula, cape, promontory, tongue of land or spit is, but with discovering one's homeland in the narrowest sense of the word - the surroundings of one's home town", V.V. Bogachev wrote (Bogachev, 1919: 1). And it was after providing such a substantiation for the relevancy of his book when he proceeded to its specific Cossack content: "Having no love for one's homeland is unnatural. <...>. A Professor at the Kharkov University, N.D. Borisyak, whose works we will mention below more than once, was amazed how Cossacks loved their Don and held it in great awe" (Bogachev, 1919: 2-3). The compilers of the "Don chrestomathy" put it even more articulately: "The prime purpose of the Don Chrestomathy is to provide the younger generation, future citizens of the Don land and the Russian state, with material for after-school reading and with samples to study various types of fine prose and poetry. The content of the book should contribute to the free comprehensive discovery by readers of their home land" (Donskaya khrestomatiya, 1918: b. s.). And again, Cossack leanings were only outlined after these general words: "It is a conscious love for their Fatherland, elevated to readiness to make sacrifices, can edify a young Cossack into a 'faithful, sensible and useful servant of the Almighty Don Host"” (Donskaya khrestomatiya, 1918: b. s.).

Hence, "Essays on the geography of the Almighty Don Host", created amid the Civil War, were supposed to nurture a love for their home land, for the Quiet Don, and a willingness to make sacrifices for its sake in the students of Don schools. The text, however, did not touch upon ideological issues that tore apart the Cossack elite at that time - it stressed neither the monarchism of Cossacks, nor their devotion to democratic traditions and involvement in popular uprisings; it pinpointed the particularism of the Don region on the one hand and emphasized an inextricable connection between the land Russia on the other one, etc. But the propaganda of the military predestination of Cossacks and their natural superiority over Great Russians was presented full force on the pages of the book of interest to us. And our paper will make an attempt to analyze precisely these features of the propaganda. 


\section{Materials and methods}

As a main source, our research will use the text of "Essays on the geography of the Almighty Don Host". For this reason, it is appropriate to briefly describe the structure and peculiarities of the textbook, as well as portray the personality of its author. His autobiography, which was written in 1960 and can now be accessed on the website of the RAS Geological Institute, says that V.V. Bogachev was born in Novocherkassk in 1881, studied at a Novocherkassk gymnasium and already at the time established a collaboration with the Don Museum (Bogachev, 1960). The museum was headed by Kh.I. Popov, not only an eminent Don scholar, but a person with very right-wing beliefs, who as early as before 1917 put a high value to P.N. Krasnov. A historian of Don nationalism, B.S. Kornienko noted that the Donskie Oblastnye Vedomosti newspaper, edited by Kh.I. Popov, reprinted almost all articles by P.N. Krasnov from Russky Invalid daily (Kornienko, 2013: 93). V.V. Bogachev was a graduate of St. Petersburg University and later a teacher of geology at Yuryev University. Despite this, he continued to maintain contact with the Don administration - he prepared a soil map of the Don Host Oblast as commissioned by the military authorities (Bogachev, 1960).

V.V. Bogachev described his activities during the Civil War very briefly: in 1917, he was offered a teacher position by Kharkov University and Polytechnic Institute in Novocherkassk, and of the two offers he chose Novocherkassk (Bogachev, 1960). It goes without saying that a Soviet scholar should not make mention of his contacts with the regime of P.N. Krasnov. Nevertheless, the contacts seemed to be no coincidence: in 1943, V.V. Bogachev was arrested for "staying in the occupied territory", he wrote (Bogachev, 1960). However, there is information that the respected professor of geology was in Rostov-on-Don, occupied by Germans, for a reason, as he was a member of the Special Commission for Cossack Affairs, created by Nazis (Problema kazachestva..., 2010). Unfortunately, there are no dedicated biographical research about V.V. Bogachev, but, apparently, not only was he an excellent geographer who taught for many years in higher educational institutions both in the Russian Empire and the USSR, but he also clung to far right views, and specifically far right views with the Cossack bias, like P.N. Krasnov and Kh.I. Popov. At least, the content of "Essays on the geography of the Almighty Don Host" confirms this suggestion.

V.V. Bogachev himself considered "Essays on the geography of the Almighty Don Host" not a very good book: he wrote that what he felt about the work was "not even dissatisfaction", but "an ultimate, clear realization of its unsatisfactory nature" (Bogachev, 1919: 516). V.V. Bogachev pointed out a whole range of shortcomings in his work, caused by the haste, in which he worked, volume limitations and the unusual task to develop a new genre for Don historiography - geographical essays for schools. First, V.V. Bogachev "examined nature, but overlooked individual", meaning that purely geographical sections prevailed over ethnographic topics in his book (Bogachev, 1919: 516). Still, he wrote in his defense that works on Don ethnography had always been voluminous, and even a concise but adequate description of the people, living in the Don region, would take more than half of the number of sheets, agreed for his publication, and P.N. Krasnov personally advised him to concentrate on geography and said that the issues of Don ethnography were planned to reflect in the "Don chrestomathy" (Bogachev, 1919: 516). Second, despite thus divided scopes, the ethnographic section in "Essays on the geography of the Almighty Don Host" turned out to be too big for the text volume planned for publication, and the author had to shorten it, "which totally violated the harmonious balance of the parts" (Bogachev, 1919: 517). Third, V.V. Bogachev was criticized for introducing an extensive historical element into his textbook and for his excessively close attention to historical aspects at the expense of geographic and ethnographic descriptions (Bogachev, 1919: 517). Finally, V.V. Bogachev admitted that he could also be accused of Kazakomanstvo (Cossack-mania), but argued that his book was characterized not by Kazakoman inclinations, but by "a love for Cossacks" (Bogachev, 1919: 519). Yet, even the explanations supplemented for the book made it clear that the love was discriminative: for example, without viewing Cossacks as a "distinctive tribe", V.V. Bogachev not only said that Cossacks could have evolved into such a tribe if the circumstances had played out differently, but also argued that Cossacks were a stronger and happier social class than most nonCossacks, which explained why the latter were hostile towards them (Bogachev, 1919: 518-519). It is easy to see: the work was far from being perfect as the author himself provided so many excuses in the afterword to his book.

In fact, "Essays on the geography of the Almighty Don Host" was a repetition, to a greater or a lesser extent, of the typical structure found statistical descriptions of Russian regions. V.V. Bogachev called the book "Nature and population of Sloboda Ukraine" (Priroda i naselenie Slobodskoy Ukrainy), 
published in 1918 in Kharkov, as a model he was guided by (Bogachev, 1919: 517). However, similar works about the Don Host also existed. Although V.V. Bogachev admitted that he advanced the tradition of statistical descriptions, introduced by V.D. Sukhorukov, N.I. Krasnov and S.F. Nomikosov, he believed that all the works became out-of-date (Bogachev, 1919: 4). Ironically, even before Bogachev published his own book, critics, who read its drafts, commented that 4/5 of the material simply retold its precursors and therefore was often obsolete (Bogachev, 1919: 515). Indeed, even if we take the overall structure, V.V. Bogachev generally followed the same plan as his predecessors. For example, the volume about the Don Host Land, published by N.I. Krasnov in the "Materials for geography and statistics of Russia, collected by officers of the General Staff" series back in 1863, included 8 sections: a historical overview, a geographical and topographic description, a description of the physical properties of surfaces, characteristics of plants and animals, characteristics of inhabitants, an overview of industry, an overview of education and an overview of the life in the Don Host (Krasnov, 1863: I-III). S.F. Nomikosov's "Statistical description of the Don Cossack region" was comprised of 19 chapters organized in a similar order: first history, then geography, then a general description of the population, followed by a description of the life and governance system in the Don region (Nomikosov, 1884: I-XV). Accordingly, V.V. Bogachev's work is interesting for its deviations from the traditional structure of statistical descriptions, and the novelty is in replacing a comprehensive historical section with historical digressions in the introductory section and in the section on the Don population, as well as in adding a section on individual districts of the Don Host (Bogachev 1919: b. s.). As for our research interest with regard to V.V. Bogachev's book, it primarily concerns the historical lines and episodes, included into the textbook on geography, for which, as we can see, the author was disapproved by his contemporaries. Significantly, V.V. Bogachev used a format to present historical facts other than his predecessors, earlier Cossack authors of statistical Don Host descriptions, who scrupulously and thoroughly dug into historical issues in dedicated sections or chapters. He revised their practice by inserting historical statements, usually without detailed discussions of pros and cons, into the body of geographic and ethnographic text as a matter-of-course fact. At the same time, as V.V. Bogachev himself admitted some of his statements also were at variance with "the most popular literature", but the Don geographer felt it was his "moral right to think this way and not otherwise" (Bogachev, 1919: 517-518). And the approach enabled V.V. Bogachev to put a number of very controversial ideas into his textbook, which, however, were in line with the policy of the P.N. Krasnov administration.

It is no accident that we elaborated at length on the features of "Essays on the geography of the Almighty Don Host". Before everything else, out intention was to show that the book was created in a hurry, was not checked, and hopefully, despite all its imperfections, more accurately and sincerely reflects the position of its author on controversial political issues. "Essays" arouse interest not only considering the facts they contain, but also as a document created in a blazing and bloody era. In view of this, our research will broadly use both comparative and descriptive methods of historical analysis to reconstruct the features of military propaganda in the book.

\section{Discussion}

The engagement of Cossacks in the Civil War was and remains one of the dominant themes in the Don regional historiography. Following the collapse of the USSR, the subject was covered in print both in monographs (we would specifically highlight the works by V.P. Trut (Trut, 1997) and A.V. Venkov (Venkov, 2008), as well as in dedicated collections of documents (Don v gody revolyutsii..., 2017). However, issues, related to the propaganda of the White Cossack Don government, were peripheral to most researchers. For example, the monograph by Yu.V. Grazhdanov “The Almighty Don Host during the Civil War (1918-1919)" (Vsevelikoe Voysko Donskoe v gody Grazhdanskoy voyny (1918-1919)) devoted several pages to the activity of White propagandists already under A.P. Bogaevskii, with a primary accent on the inefficiency of their exercises (Grazhdanov, 2015: 213-215). It is only the recent decade that has brought about publication of research papers with a key focus on the Don anti-Bolshevik propaganda during the Civil War, but they typically describe the period of A.P. Bogaevskii's atamanship and the organization of propaganda agencies (Egorov, 2013; Kirichenko, 2015). Peculiar characteristics of propaganda forms, especially of indirect one, through textbooks, have not been subject for study so far.

Modern authors also paid certain attention to the personality of V.V. Bogachev. Nevertheless, as it was mentioned above, there are no specialty biographical works about him. His legacy actually turned out to have a rather curious fate. V.V. Bogachev as a professional and competent geologist is 
extensively spotlighted by so-called "atlantologists", supporters of the existence of Atlantis, who position him as "the founder of Russian scientific Atlantology" (Fanagorov, b.g.). V.V. Bogachev allegedly published in 1912 a book "Atlantis - mythical Atlantis and geological Atlantis" (Atlantida - Atlantida mificheskaya i Atlantida geologicheskaya), which, while denying the existence of "political Atlantis", depicted by Plato, insisted on the existence of "geological Atlantis", a bridge between Europe and America in the prehistoric era (we failed to find a copy of the book, and atlantologists in their descriptions refer to each other (Fanagorov, b.g.). Speaking of other writings by the Don geographer, it is remarkable that the greatest prominence was acquired right by "Essays on the geography of the Almighty Don Host", which were repeatedly appreciated by Don regional historians in the post-Soviet period, but most often they limited themselves to a short summary of the work. The only paper worthy of note is I.Yu. Yurchenko's article "V. Bogachev's textbook 'Essays on the geography of the Almighty Don Host' of 1919 as a source on the history of the Don ecology and independent Cossack historiography", although it only provides some of the features of the book under review (Yurchenko, 2013).

\section{Results}

Although the book appeared in a very eventful time, "Essays on the geography of the Almighty Don Host" makes no explicit mentions of Bolsheviks. Apparently, V.V. Bogachev understood that such mentions in the work on Don geography and ethnography would be inappropriate, al the more that he positioned himself as a person of "academic mold", a scientist who followed the "templates of scientific research" (Bogachev, 1919: 517). However, his unconcealed partiality and love for the Cossackdom made it impossible for him to completely leave out the fact of Cossacks' role in what was deemed a fight against the forces destructive to Russia. It might be the reason why V.V. Bogachev supplemented the book's introductory section with subsections not only with basic geographical features of the Don Host Land, but also about the history of the region (Bogachev, 1919: 9-14). The composition indeed, as his critics noted, could not be regarded as a felicitous choice: a compressed overview of the Don history, from Scythians to 1918, on several pages inevitably was very chaotic, and a number of the facts it contained were repeated later.

Nevertheless, the chaotic retelling of a mainly ancient history found was explained and justified at the end where it became clear why part had pivotal importance and was not thrown out when the book was shortened. V.V. Bogachev, who more than once emphasized the strategic meaning of the Don region, which for long was a cherished prize for different competing forces, called Rostov-on-Don "the heir of Tanais the First", "Tanais the Fifth" (Bogachev, 1919: 14). He stressed that the struggle for this new Tanais was not over yet, and again, as in ancient times, "both peaceful colonists and armed crowds of half-wild people flocked to the Don" (Bogachev, 1919: 14). And V.V. Bogachev's most significant argument deserves to be quoted in full: "As the disproportionately replenished peoples of Asia, pushed by poverty, land shortage and scarcity of nature, came together and assaulted prosperous countries, bringing destruction, ruining world culture, unable to create anything themselves, and carried the germs of degeneration inside themselves, so in our days the Don region found itself on the way of those who have lost faith in themselves, in the future, and, most importantly, their love for their homeland" (Bogachev, 1919: 14). Moreover, V.V. Bogachev made an attempt to provide geographical reasons why the situations, in which Don would stand as a borderline between civilization and barbarism, would inevitably repeat in the future: "While the outlying areas of the East European Plain have barriers of their own: the wooded Carpathians, seas, marshes, Arctic Ocean, Ural Mountains, deserts, Caucasus, where nature or human infallibly withstand disorderly hordes - our land is exposed to their raids from all directions like to the winds" (Bogachev, 1919: 14).

In principle, the ideas were not original. The opinion that Cossacks were military defenders of certain positive values was time and again voiced by Don authors as early as in the 19th century. For example, V.V. Bogachev referred to the works of V.M. Pudavov, a half-forgotten Don amateur historian (Bogachev, 1919: 233). Meanwhile, V.M. Pudavov wrote about the high mission of Cossacks as military defenders of Christianity in a somewhat florid style: "With sublime pride, the Cossack realizes that the heroic soil and burial mound of Tanais, which gave birth to him and raised him, from the depths of preRurik times and until now, only nourished a man who worships the sword. $\langle\ldots\rangle$. For him, alive and sacred are the legends of the forefathers, who three centuries ago deeply understood the significance of their bunchuk - 'all lands envied our Cossack life', they said, 'Then we shall stand up for Christ, so that we may not waste our ataman glory and valor, so that our tsar's name may not be reviled in other 
lands"' (Pudavov, 1895: 15). The tendency to compare revolutionaries not simply with barbarians, but with old-time enemies of Cossacks, emerged in Don historiography after the 1905-1907 Revolution. For example, here is what P.N. Krasnov, who commissioned to create "Essays on the geography of the Almighty Don Host", noted in his "Pictures of the past Tikhii Don": "Time after time, Don Cossacks held Russia against external and internal enemies; it was not long ago - in 1855, the entire host took up arms against Turks; under Peter, Cossacks quelled Astrakhanites and Bulavin, they fought under Catherine and against Pugachev - now the Tsar called upon them to protect the Russian people and Russian cause from insurgents, who under the banner of freedom wanted to plunge Russia into shame and slavery" (Krasnov, 1909: 516).

Hence, by translating the fight against Bolshevism as a logical continuation of the Don region history, V.V. Bogachev expanded on a specific historiographic tradition. The author's fresh move is not in suggesting the ideas themselves, but in including them in the introductory section to the textbook on geography, as well as in an attempt to interpret the Don's warlike history through its geographical position - the absence of natural boundaries that could guard against "disorderly hordes". We can see V.V. Bogachev presented the fight against Bolsheviks in his book only as an episode in Cossack history, and the very geography of the homeland compelled a young Cossack to prepare to defend it from new enemies in the future. And, naturally, the propaganda of the military service and preparedness to defend Russia and the Don from any new enemies became a prominent thematic line in "Essays on the geography of the Almighty Don Host", which included implicit anti-Bolshevik propaganda as an insignificant component.

However, the ethnographic subject and the focus on the current condition of the Don Host were obstacles for the fairly dutiful V.V. Bogachev: while his historical digressions regularly emphasized the military role of Cossacks, the descriptions of contemporary Cossacks rather demonstrated the decline in military traditions in Cossack stanitsas. As a consequence, many parts of his text convey a somewhat ambiguous impression, and sometimes it is not even totally clear what the author meant to say. For example, "Essays on the geography of the Almighty Don Host" began with a brief untitled section that provided acknowledgements and a small lyrical text of V.V. Bogachev himself. He underlined there that the Don "combined elements of the present with a glorious past": "A speechless guardian of steppes, a stone baba, a nomad knight, stands at the root of foundation: he envisions the future arrangement of life and history of the Wild Field, the Great Meadow, the Don steppes. In the expanse of the steppe, primordial Scythians tame horses - a pre-image for the dashing Cossack cavalry of our era. The picture is taken from the belt of a vase unearthed in southern Russian barrows. Cossack freemen, reveling and bellicose, look at us from the seal of the Don Host" (Bogachev, 1919: b. s.). However, the geographer admitted later that all this "was once, but now is long forgotten", and the Don experienced a different era, the era of farmers and miners, rather than warriors (Bogachev, 1919: b. s.). But, having admitted the fact, V.V. Bogachev again altered the course of his reasoning, and ended his lyric text with the following maxim: "The black shapes of the mines are merely a shadow of the White Cossack Cathedral. It renders aspiring upward, to the sky, to the kingdom of the Spirit, and the mine is to plunge into the depths, in search of earthly riches" (Bogachev, 1919: b. s.).

In general, V.V. Bogachev's description of Cossacks infers a similar contradiction. On the one hand, he provided a lot meticulous episodes from the past of Cossacks (excessively meticulous for a geographic textbook of limited size), putting a clear emphasis on military history and idealizing bygone days of Cossacks. On the other hand, he admitted that Cossacks of his time differed drastically from the Cossacks who lived only fifty years ago. His general notion of Cossackdom was that of an estate equal to the Russian aristocracy and superior to all other estates in the former empire: "Three centuries ago, Cossacks performed the same duty to the state as nobles with boyar children, so it is understandable why they sought a reward of the same measure. The privileges of the Don Host were bestowed on them by tsars for their great service. As early as under Tsar Aleksey Mikhaylovich it was written by Kotoshikhin that but for the help of Cossacks, Ivan the Terrible would not have conquered the Tsardoms of Kazan and Astrakhan" (Bogachev, 1919: 270). However, contemporary Cossackdom was depicted by him as a class going into decline and losing their former military strength. V.V. Bogachev not only blatantly wrote that "the situation is different nowadays: a Cossack has become a farmer" but also gave descriptions of the following sort: "Indeed, have been preserved and brought up since childhood through stories, examples, competition and ancestral Cossack pride - military honor and deftness, a desire to excel in battle trials, courage is an hereditary quality, but the love for weapons and custom to parade them do not 
exist any longer" (Bogachev, 1919: 271). Parallel to the decline of military traditions, other instances of the fine Cossack culture also seemed to recede into the past: "The Don folk song has been now fading from memory and has been substituted by verses of the all-Russian production, with mediocre composition and set to poor music" (Bogachev, 1919: 262-263).

Therefore, the high duty of military service was rather described by V.V. Bogachev as some unattainable ideal, most noble and useful for the native land, but quickly receding into the past. Here, again, he lacked originality. As early as in the late 19th century, the Cossack society was pervaded with the tendency to idealize olden times and with the belief that the historical Don Host Land was not a wild and dangerous frontier, but a prosperous country of heroes. As N.A. Maslakovets, a distinguished expert on the Don region, Assistant to Host Atamans N.A. Krasnokutskii and N.I. Svyatopolk-Mirskii, said, "a Cossack of the Don was perhaps for too long enchanted with the beauties of these epic tales, which is why he missed that vitally important moment in the economic life of nations, when victory is claimed by those who are more artful and far-sighted in the fight in the market of life, while plows and rakes can beat both sharp swords, and thundering cannons" (Maslakovets, 1899: 6). One cannot but agree with N.A. Maslakovets: even V.V. Bogachev, as he embedded propaganda elements into his textbook and championed the idea of the Don Cossackdom as a military force there, could never distinctly formulate those purely Cossack values that Cossacks would stand up for (to put it more precisely, his formulation of the values was very peculiar and xenophobic, and we will write about it in more detail below). In addition, the facts he provided allowed a suggestion that Cossackdom with its historical particularism tended to sink into decline, and the process was objective and imminent brought about by rising agriculture and manufacturing production in the Don region.

Returning to the question of what Cossacks, according to V.V. Bogachev, defended, note should be taken that he paid special attention to the profound Christian faith of Don Cossackdom. "Cast away by the twist of history and the miserable lot of Russia on the borderlands of Russian lands, Cossacks staunchly adhered to the Orthodox Greek Russian religion. They were very pious, and their only calamity was that they had no priests", the geographer wrote about the early history of Cossackdom (Bogachev, 1919: 263). However, in his interpretation, Cossacks of his time also firmly adhered to Orthodoxy, and, significantly, without superstitions and with a "wise and calm attitude" towards religion (Bogachev, 1919: 265). Interestingly, V.V. Bogachev also put Old Ritualist Cossacks into Orthodoxy in the broader sense of the word, insisting that Old Ritualists "differ from Church Orthodoxy only in certain liturgical practices, rituals and prayers" (Bogachev, 1919: 267). "Sectarianism", however, (for example, baptism) was condemned by V.V. Bogachev who nevertheless noted that it was not widespread among Cossacks. To his mind, "the purpose of sectarianism is to justify the foulest human motives: treachery, refusal to take an oath not only of allegiance to one's motherland and the tsar, but also in the course of judicial investigations, a desire to justify debauchery or cowardice in wartime (one may not kill) or simply unwillingness to perform one's state or public duty" (Bogachev, 1919: 267-268). Hence, one of the traditional Cossack values, which Cossacks defended in the Civil War, according to V.V. Bogachev, certainly was the Orthodox faith.

However, the defense of the Orthodox faith could by no means be regarded as an exclusive Cossack characteristic. And further V.V. Bogachev proceeded to what could actually be construed only as explicit Kazakomanstvo. He attributed a whole range of peculiar features to Cossacks, which were shaped by military service and compelled them to love their birthplace in a unique way beyond the comprehension of "Russians" (Great Russians and Little Russians). "The life in fights and camps evolved a tremendous sense of camaraderie in Cossacks, unknown to those born in the peaceful countries of central Russia and Little Russia”, he argued (Bogachev, 1919: 268). From the sense of camaraderie, V.V. Bogachev derived the special love of Cossacks for their native land, also allegedly incomprehensible to Russians: "In fact, remarkable is the love for one's village, the pride in belonging to it, an instinctive pride in its entirely obliterate glorious past. This does not exist in peaceable Russia" (italicized by V.V. Bogachev) (Bogachev, 1919: 268). And, building on all these ideas, V.V. Bogachev ended up by contrasting Cossacks not with Bolsheviks any more, but with Great Russians in general, considering the former to be bearers of loftier moral qualities: "Cossacks treat each other with cordial, friendly trust or simply as if they were a family, as opposed to Great Russians who are envious and suspicious" (Bogachev, 1919: 269). On this premise, V.V. Bogachev fully excused Cossacks' arrogant attitude towards non-Cossacks, as towards people of the "inferior estate", arguing that the attitude was completely "explained by history" (Bogachev, 1919: 269-270). Hence, in V.V. Bogachev's 
understanding, Cossacks should defend Cossackdom itself in the first place. Furthermore, in his opinion, a love for one's homeland and ancestral traditions was beautiful and should be nurtured in children even if there was no objective underlying basis: "So a child does not see the ugliness of its mother, even after it feasted its eyes on the beauty of other women" (Bogachev, 1919: 2).

As a result, V.V. Bogachev's text took form of propaganda not so much against Bolsheviks as against Great Russians in general and primarily against Don peasants. Many accusations and insults were leveled at them, concealed by outward impartiality. For example, V.V. Bogachev in every possible way emphasized the uncleanliness of peasants in expressions like this: "Peasant homesteads are much dirtier than those of Cossacks, terribly soiled with manure, whereby a multitude of fleas and flies hatch (their larvae feed on dung)" (Bogachev, 1919: 341). Describing the interior of peasant houses, V.V. Bogachev noted that their the comparatively simplistic inner part was explained "partly by peasants' poverty in comparison with Cossacks", but immediately added that peasants generally had "uncultivated tastes" and lacked "the inclination for exquisitism and dapperness" (Bogachev, 1919: 340). However, moving on to the description of Taurida natives, wealthy migrants from the Taurida and Yekaterinoslav Governorates, V.V. Bogachev did not at all see fit to highlight in some positive way their large and robust houses with a well in every courtyard (on the contrary, he criticized the houses for their allegedly standard style as compared to the Cossack style) (Bogachev, 1919: 344-345). While the geographer depicted the impoverished peasantry in the unreservedly pejorative manner for poverty and untidiness, Taurida natives were accused of "disagreeable insolence and rudeness in their treatment" (apparently, of Cossacks), stemming from their being "conscious of wealth and independence" (Bogachev, 1919: 346). And, naturally, speaking about Don peasants, V.V. Bogachev again made a reference to events of the time, pointing out that "class hatred and envy of their neighbors who have land plots (i.e. of Cossacks - A.P.) evoke deaf hostility that became particularly visible in 1917-1919" (Bogachev, 1919: 339).

And again V.V. Bogachev only carried on a tendency that characterized an earlier period. In an ad hoc government commission led by N.A. Maslakovets and created in 1899 to identify root causes behind Cossacks' impoverishment, stanitsa delegates and members of the Don aristocracy did not hesitate to labeling peasants as "leeches" that allegedly sucked juice from Cossack farms (Protokoly..., 1899: 104). The Don right-wing press of the early 20th century non-Cossack peasant settlers inogorodnie - were blatantly compared with Jews, allegedly, as "God-sellers, who will not yield to any Israel in profiteering" (Kornienko, 2013: 182). However, the official imperial rhetoric, with few exceptions, did not support the opinion. First of all, it was considered offensive by Russian officials who served in the Don region. For example, A.A. Chigrintsev, the Novocherkassk prosecutor, commented in his private letter to N.A. Maslakovets on the statements made by the members of the latter's commission: "It is quite a shock for someone who is not a Cossack to perceive the somewhat hostile attitude of Cossacks towards the so-called inogorodnie, who, according to the law of 1868, gained the right to buy real estate in the Don Host. <...>. In this case, Cossacks forget the natural law according to which as nature does not tolerate emptiness, so uncultivated land attracts working people, and if the latter are not in sufficient quantity in the area, they come from the outside. Besides, the inogorodnie, as farmers, turned out to be more civilized than Cossacks. We resent Belgians for seizing and exploiting our abundant mineral resources, but this resentment is like the vexation of a child who is able to overcome an adult" (OR RNB. F. 1055. Ed. khr. 24. L. 5-6). A major pre-revolutionary ethnographic study of the Don region, conducted by M.N. Kharuzin, directly said that Cossacks humiliated and discriminated against Russian (Great Russian) peasants, although the former totally relied on the help of the latter in in farming (Kharuzin, 1885: XXVIII).

Therefore, peasants were pinpointed as a danger threatening Don Host Cossacks long before it was done by V.V. Bogachev. However, the views were considered marginal and pertaining to Kazakomanstvo in the official discourse. The fact that they jeopardized stability in the Don region was obvious: according to V.V. Bogachev's own estimate, Cossacks accounted for only $42.7 \%$ of the Almighty Don Host population, which meant they were already a minority (Bogachev, 1919: 258). And this time the opinion was voiced not simply in an official edition, but in a textbook intended not only for Cossacks, but for all schools in the Don region. Although V.V. Bogachev avoided writing about this in an explicit fashion, the very logic of his text allowed an inference that Cossacks should be prepared to defend their land not only from Bolsheviks, but also from peasants in principle. In this context, it is interesting that V.V. Bogachev bluntly demonized Taurida natives, the best-off and most influential group of Don peasants, accusing them of betraying Orthodoxy and sectarianism: "There are no 
churches in their villages. Utmost materialism is combined with malicious litigation and miserliness. $<\ldots>$. At the same time, remarkably widespread among them are all sorts of sectarianism. Yet, even in this Taurida people push any kind of advantages and benefits: dodging from military service, evading from paying for church services and more" (Bogachev, 1919: 346). In fact, he pre-emptively offered excuses for possible repressions against the ethnic group by the Cossacks as repressions against an antisocial and malicious population. It is appropriate to note here that, according to P.N. Krasnov himself, the administration of his predecessor, A.M. Kaledin, "was ruined by their trust in peasants", "the wolves in sheep's clothing" (Grazhdanov, 2015: 143). P.N. Krasnov called peasants "guests in the Don region", and, although in the end he allowed them minimum representation in the elected bodies, he arranged parallel punitive expeditions to cleanse villages of those who supported Bolshevism and land reallotment ideas (Grazhdanov, 2015: 143-144).

V.V. Bogachev even argued that the Razin and Bulavin Rebellions were actually sparked off not by Cossacks, but by peasants who had fled to the Don. As proof, he referred, however, not to historical sources, but to a folk song:

"Stepanushka did not ever come to the Cossack Assembly,

Nor did he, with us, Cossacks, meditate on things;

He caroused, he went, Stepanushka, to the tsar's tavern

He devised a plan with the golutva (golytba (the rural and urban poor) - A.P.)" (Bogachev, 1919: 270).

As for Cossacks, they allegedly "pitied" the peasants who came to the Don region, but at the same time "kept themselves separate from the muzhik who did not belong here" (Bogachev, 1919: 270).

In principle, the opinion was also expressed more than once earlier. For example, in the 1880 s, S.F. Nomikosov, a Don statistician, gave the following description of the Razin Rebellion: "At the end of the first century <of the history of Cossackdom>, the word of brigands' ataman Stenka Razin was spread across the Don, calling on 'brothers, tavern riff-raffs to sail to the blue sea, to pillage ships of infidels" (Nomikosov, 1884: 19). However, in the context of the Civil War and aggravating antagonism between Don Cossacks and Don peasants, such a suggestion that the "Cossack" revolts were in fact allegedly raised by Don peasant golytba, and Cossacks were engaged in their suppression - this suggestion clearly communicated a new political connotation.

Therefore, despite being a textbook on geography, "Essays on the geography of the Almighty Don Host" had a certain ingrain image of Cossackdom, which readers were supposed to take in. And the military dimension was the primary aspect of the image - it underscored the beauty of Cossacks' warlike past, the danger arising from the very geographical position of the Don region, and prophesied that the Don would more than once stand in the way of "disorderly hordes". But as glorious as the image was, it was largely built through the demonization of Don peasants, and a young Cossack who had assimilated the ideas of V.V. Bogachev, would have imbibed not only a love for his native land, but also an attitude towards Great Russians as uncleanly, "envious and suspicious" people of the second rate, claiming Cossack lands out of envy.

And in the afterword to his work, V.V. Bogachev made an attempt to explain his peculiar "love for Cossacks" but in fact he compromised it even further. We should quote all his arguments regarding the issue: "We cannot deny the laws of heredity. The traits only gradually disappear influenced by a changing environment and (marriage) mixing with members of other races and minorities. The history of innate (rather than acquired) Cossackdom could not yet dissipate from the inheritance passed down from generation to generation: this takes much more time" (Bogachev, 1919: 518). As a result, the particularism (and in essence - the superiority) of Cossacks in comparison with Great Russians was eventually justified by V.V. Bogachev by their origin and heredity. The idea expressed should not, of course, be viewed as a basis to attribute consistent fascist beliefs to the Don geographer. On the other hand, one fact is to be remembered - the initiator behind "Essays on the geography of the Almighty Don Host", P.N. Krasnov, as well as V.V. Bogachev himself collaborated with the Nazi regime during the Great Patriotic War. So, the book under review is a good example of how, in wartime, a love for Cossackdom and propagandizing love for the Don region could metamorphose into xenophobia and hatred for Great Russians.

\section{Conclusion}

The design to publish textbooks featuring some of basic elements of the ideology of the Almighty Don Host during the Civil War was rather a progressive move. However, "Essays on the 
geography of the Almighty Don Host" starkly illustrates that the ideological constructs of the Almighty Don Host in the period, when P.N. Krasnov held the ataman office, were fraught with significant limitations and contradictions. This book, together with "Don chrestomathy", was intended to nurture a love for the homeland and a willingness to defend it from "disorderly hordes" in Don school learners. However, grossly insulting the Don peasants and accusing them of envy and uncleanliness immediately halved the book's target audience among the Don population. Moreover, the book suggested that a peasant could not even hope to become a true Cossack: one could only be a Cossack, be born as a Cossack because Great Russians by birth had no many positive Cossack qualities. Note should be made that P.N. Krasnov himself addressed the subject in a much more delicate manner in the pre-revolutionary "Pictures of the past Tikhii Don": he emphasized that it took more than simply being a Don Cossack, one had to deserve the name, "to become a dashing horse warrior" (Krasnov, 1909: 521). Therefore, although "Essays on the geography of the Almighty Don Host" had a potential to consolidate in the future a new generation of Cossacks to defend their homeland from enemies, the book could only worsen the opposition between the new generation of Don peasants and Cossacks.

Moreover, V.V. Bogachev's text implied that Cossacks were no longer what they used to be, that they became increasingly weaker in their moral virtues. Perhaps the Don geographer simply tried to be impartial on the issue; perhaps by making the statements he wanted to stress the need to cling even more firmly to the customs of their ancestors. But in fact, he showed an opposite picture - if we decipher his own metaphor, it turned out that the "white Cossack Cathedral" would inevitably be replaced by "the black shapes of the mines". Generally speaking, the description of the positive ideal of Cossackdom was very unconvincing in his work: it was limited to Orthodoxy and a peculiar love for the native land and fellow countrymen, a love allegedly incomprehensible to Great Russians. All in all, it turned out that Cossacks should defend and love their native land purely out of the fact of being born in the area, without imparting any profound meaning to the love.

It only remains to conjecture how Don schools would react to V.V. Bogachev's book. Soon after its publication, the Almighty Don Host collapsed, swept away by the Red Army. At present, historians of the Don region know the book quite well and actively use it in research articles. And the appreciation is well deserved: despite the book's erratic and secondary character, which V.V. Bogachev himself realized, he managed to collect valuable information from many rare pre-revolutionary publications. However, after completing the work, he admitted that "an ultimate, clear realization of its unsatisfactory nature" came to him, and we think the opinion is quite justified. It was hardly possible that the book could achieve its prime purpose of instilling a love for the homeland in the general Don reader - its target audience were Cossacks, in particular the Cossacks who already loved not so much the Don as their social class. Many of V.V. Bogachev's statements would be unacceptable even for more broad-minded Cossacks: already P.N. Krasnov's grandfather, I. I. Krasnov advocated the rights of Don peasants, calling them "our Russian brothers in origin, language and religion, brothers who unanimously share with us devotion to the Holy Christian Faith and feeling of allegiance to the throne and fatherland" (GARO. F. 243. D. 28. Op. 1. L. 2530b-254).

\section{References}

Bogachev, 1919 - Bogachev, V.V. (1919). Ocherki geografii Vsevelikogo Voiska Donskogo [Essays on the geography of the Great Don Host]. Novocherkassk, 523 p. [in Russian]

Bogachev, 1960 - Bogachev, V.V. (1960). Avtobiografiya [Autobiography]. B.m. [Electronic resource]. URL: http://higeo.ginras.ru/view-record.php?tbl=pub\&id=604 (date of access: 29.09.2021). [in Russian]

Don v gody revolyutsii..., 2017 - Don v gody revolyutsii i Grazhdanskoi voiny. 1917-1920 [Don during the revolution and the Civil War. 1917-1920.]. T. I. Rostov-na-Donu, 2017. 460 p. [in Russian]

Donskaya khrestomatiya, 1918 - Donskaya khrestomatiya [Donskaya Reader]. Novocherkassk, 1918. 406 p. [in Russian]

Egorov, 2013 - Egorov, A.O. (2013). Otdel osvedomleniya Donskogo pravitel'stva v 1919 godu [Department of informing the Don government in 1919]. Vestrik Baltiiskogo federal'nogo universiteta im. I. Kanta. 6: 103-107. [in Russian] 
Fanagorov, b.g. - Fantagorov V. Bogachev - osnovopolozhnik russkoi nauchnoi atlantologii [Bogachev - the founder of Russian scientific atlantolog]. [Electronic resource]. URL: http://www. roipa.org/49.pdf (date of access: 29.09.2021). [in Russian]

GARO - Gosudarstvennyi arkhiv Rostovskoi oblasti [State archives of the Rostov region]. [in Russian]

Grazhdanov, 2015 - Grazhdanov, Yu.D. (2015). Vsevelikoe Voisko Donskoe v gody Grazhdanskoi voiny (1918-1919 gg.) [The Great Don Host during the Civil War (1918-1919)]. Rostov-na-Donu,. 240 p. [in Russian]

Kharuzin, 1885 - Kharuzin, M.N. (1885). Svedeniya o kazatskikh obshchinakh na Donu: materialy dlya obychnogo prava [Information about the Cossack communities on the Don: materials for customary law:]: vyp. 1. M., 432 p. [in Russian]

Kirichenko, 2015 - Kirichenko, E.V. (2015). Struktura apparata propagandy antibol'shevistskogo dvizheniya na yuge Rossii v 1919 godu [The structure of the apparatus of propaganda of the anti-Bolshevik movement in the south of Russia in 1919]. Politematicheskii setevoi elektronnyi nauchnyi zhurnal Kubanskogo gosudarstvennogo agrarnogo universiteta. 113: 865-875. [in Russian]

Kornienko, 2013 - Kornienko, B.S. (2013). Pravyi Don: kazaki i ideologiya natsionalizma (1909-1914) [The Right Don: Cossacks and the Ideology of Nationalism (1909-1914)]. SPb., 232 p. [in Russian]

Krasnov, 1863 - Krasnov, N.I. (1863). Materialy dlya geografii i statistiki Rossii, sobrannye ofitserami General'nogo shtaba [Materials for geography and statistics of Russia, collected by officers of the General Staff]. Zemlya voiska Donskogo. SPb., 596 p. [in Russian]

Krasnov, 1909 - Krasnov, P.N. (1909). Kartiny bylogo Tikhogo Dona [The pictures of the former Quiet Don.]. SPb., 522 p. [in Russian]

Maslakovets, 1899 - Maslakovets, N.A. (1899). Predstavlennye g. Predsedatelem komissii soobrazheniya po povodu dokladov gg. Mordvintseva, Biryukova i Dontsova [The views presented by the Chairman of the Commission on the reports of Messrs. Mordvintsev, Biryukov and Dontsov]. Novocherkassk, 11 p. [in Russian]

Nomikosov, 1884 - Nomikosov, S.F. (1884). Statisticheskoe opisanie Oblasti Voiska Donskogo [.Statistical description of the Don Cossack Region]. Novocherkassk, 774 p. [in Russian]

Ocherk politicheskoi istorii..., 1919 - Ocherk politicheskoi istorii Vsevelikogo Voiska Donskogo [Essay on the political history of the Great Don Host]. Novocherkassk, 1919. 105 p. [in Russian]

OR RNB - Otdel rukopisei Rossiiskoi natsional'noi biblioteki [Department of Manuscripts of the Russian National Library].

Problema kazachestva..., 2010 - Problema kazachestva perioda Velikoi Otechestvennoi voiny (okonchanie) [The problem of the Cossacks during the Great Patriotic War (end)]. [Electronic resource]. URL: https://kazak-center.ru/news/problema_kazachestva_perioda_velikoj_otechestv ennoj_vojny_okonchanie/ 2010-05-08-586 (date of access: 29.09.2021). [in Russian]

Protokoly..., 1899 - Protokoly Komissii po issledovaniyu nuzhd kazach'ego naseleniya Donskoi oblasti [Protocols of the Commission for Researching the Needs of the Cossack Population of the Don Region]. B.m., 1899. 289 p. [in Russian]

Pudavov, 1895 - Pudavov, V.M. (1895). Vzglyad na osnovnye nachala Donskogo kraya [A look at the main principles of the Don region]. Novocherkassk, 15 p. [in Russian]

Trut, 1997 - Trut, V.P. (1997). Kazachii izlom. Kazachestvo Yugo-Vostoka Rossii v nachale XX veka i v period revolyutsii 1917 goda [Cossack break. Cossacks of the South-East of Russia at the beginning of the 2oth century and during the 1917 revolution.]. Rostov-na-Donu, $253 \mathrm{p}$. [in Russian]

Venkov, 2008 - Venkov, A.V. (2008). Ataman Krasnov i Donskaya armiya [Ataman Krasnov and the Don Army]. 1918 god. M., 479 p. [in Russian]

Yurchenko, 2013 - Yurchenko, I.Yu. (2013). Uchebnik V. Bogacheva «Ocherki geografii Vsevelikogo Voiska Donskogo» 1919 g. kak istochnik po istorii ekologii Dona i samostiinoi kazach'ei istoriografii [V. Bogachev's textbook "Essays on the geography of the Great Don Host" in 1919 as a source on the history of Don ecology and independent Cossack historiography]. Vestrik uchebnometodicheskogo ob"edineniya po obrazovaniyu v oblasti prirodoobustroistva i vodopol'zovaniya. 5: 367-381. [in Russian] 